\title{
Intraperitoneal mesenchymal stem cell administration ameliorates allergic rhinitis in the murine model
}

\author{
Sakine Işık ${ }^{1} \cdot$ Meral Karaman ${ }^{2}$ Aysun Adan ${ }^{3} \cdot$ Müge Kıray $^{4} \cdot$ Hüsnü Alper Bağrıyanık ${ }^{5}$ \\ Şule Çağlayan Sözmen ${ }^{1}$ İlknur Kozanoğlu ${ }^{6}$ Özkan Karaman ${ }^{1}$ Y Yusuf Baran ${ }^{3}$ • \\ Nevin Uzuner ${ }^{1}$
}

Received: 12 April 2016/ Accepted: 22 June 2016/Published online: 5 July 2016

(C) Springer-Verlag Berlin Heidelberg 2016

\begin{abstract}
Previous studies showed that bone marrowderived mesenchymal stem cells (BMSCs) could ameliorate a variety of immune-mediated and inflammatory diseases due to their immunomodulatory and antiinflammatory effects. In this study, we developed a mouse model of ovalbumin (OVA) induced allergic inflammation in the upper airways and evaluated the effects of the intraperitoneal administration of BMSCs on allergic inflammation. Twenty-five BALB/c mice were divided into five groups; group I (control group), group II (sensitized and challenged with OVA and treated with saline-placebo group), group III (sensitized and challenged with OVA and treated with $1 \times 10^{6} \mathrm{BMSCs}$ ), group IV (sensitized and challenged with OVA and treated with $2 \times 10^{6}$ BMSCs), and group $\mathrm{V}$ (sensitized and challenged with phosphate buffered saline (PBS) and treated with $1 \times 10^{6}$ BMSCs). Histopathological features (number of goblet cells, eosinophils and mast cells, basement membrane, epithelium thickness, and subepithelial smooth muscle thickness) of
\end{abstract}

Sakine Iş1k

drsakinekar83@hotmail.com

1 Department of Pediatric Allergy and Immunology, Dokuz Eylul University, Balçova, 35330 Izmir, Turkey

2 Department of Microbiology, Dokuz Eylul University, Izmir, Turkey

3 Department of Molecular Biology and Genetics, Izmir Institute of Technology, Izmir, Turkey

4 Department of Physiology, Dokuz Eylul University, Izmir, Turkey

5 Department of Histology, Dokuz Eylul University, Izmir, Turkey

6 Department of Hematology, Başkent University, Adana, Turkey the upper and lower airways and BMSCs migration to nasal and lung tissue were evaluated using light and confocal microscopes. Levels of cytokines in the nasal lavage fluid and lung tissue supernatants were measured using enzymelinked immunosorbent assay (ELISA). Confocal microscopic analysis showed that there was no significant amount of BMSCs in the nasal and lung tissues of group V. However, significant amount of BMSCs were observed in group III and IV. In OVA-induced AR groups (group II, III, and IV), histopathological findings of chronic asthma, such as elevated subepithelial smooth muscle thickness, epithelium thickness, and number of goblet and mast cells, were determined. Furthermore, the number of nasal goblet and eosinophil cells, histopathological findings of chronic asthma, and IL-4, IL-5, IL-13, and NO levels was significantly lower in both BMSCs-treated groups compared to the placebo group. Our findings indicated that histopathological findings of chronic asthma were also observed in mice upon AR induction. BMSCs migrated to the nasal and lung tissues following intraperitoneal delivery and ameliorated to the airway remodeling and airway inflammation both in the upper and lower airways via the inhibition of $T$ helper (Th) 2 immune response in the murine model of AR.

Keywords Allergic rhinitis - Asthma - Intraperitoneal route $\cdot$ Mesenchymal stem cells $\cdot$ Murine model $\cdot$ Th2

\section{Introduction}

Allergic rhinitis (AR) is a common chronic disease characterized by the symptoms of sneezing, rhinorrhea, itchiness, and nasal congestion. AR is a global health problem affecting $10-30 \%$ of adults and $20-40 \%$ of children [1]. Patients with AR show an inflammatory IgE-mediated 
response characterized by Th2 immunological pattern together with mast cells, goblet cells, and eosinophil activation, as well as the release of inflammatory mediators, such as IL-4, IL-5, and IL-13, against allergen exposure [2]. Multiple treatment options, including medical treatment, immunotherapy, intranasal saline, and surgery, are available. Even though the medical treatment is the cornerstone in the AR management, the recurrence of symptoms and development of adverse effects are common problems due to the drug withdrawal. Therefore, treatment modalities with improved safety profiles are required.

Mesenchymal stem cells (MSCs), multipotent progenitor cells derived from the bone marrow, contribute to the maintenance and regeneration of various connective tissues, including bone, muscle, adipose, and cartilage [3, 4]. On the other hand, MSCs demonstrate their potent immunomodulatory and anti-inflammatory effects in various pulmonary conditions $[5,6]$ and decrease the tissue damage and/or increase the repair in response to injury upon migrating to the lung [7-9]. Therefore, in the previous studies, MSCs-derived bone marrow, adipose tissue, and pluripotent stem cells were shown to attenuate allergic responses in allergic airway diseases [6, 10-14].

The main aim of this study is to evaluate the migration of bone marrow-derived mesenchymal stem cells (BMSCs) to the nasal mucosa following their intraperitoneal delivery, the impact of BMSCs on nasal histopathology, and Th2 immune responses in the murine model of AR. Besides, we also aim to determine the histopathological findings of chronic asthma, evaluate the migration of BMCSs to the lung tissue, and, finally, effects of BMSCs on the lung tissue in this particular murine model of AR.

\section{Materials and methods}

\section{Animals and experimental procedures}

Conventionally raised, 6- to 8-week-old, 25 male BALB/c mice (18-20 g) were used in the study. Mice were housed in hygienic macrolen cages in the air conditioned room with ad libitum access to food and water, and they were exposed to a 12-h light/dark cycle. All experiments were carried out according to the protocols approved by the local animal use and care committee (Ethic committee number: $05 / 2012$ ). In the study, procedures were applied in line with the standard protocols of Guide for the Care and Use of Laboratory Animals which were prepared by the Institute of Laboratory Animal Resources and published by the National Academy Press, National Research Council, Commission of Life Sciences, and the Institute of Laboratory Animal Resources.
BALB/c mice were chosen to establish the OVA-induced mouse model of AR due to their good responses to OVA [15]. After acclimatization of animals to the laboratory conditions, an AR model was established as previously described [16]. Twenty-five BALB/c male mice (7-8 weeks of age) were equally and randomly distributed into five groups as following: group I (control group), group II (sensitized and challenged with OVA and treated with saline-placebo group), group III (sensitized and challenged with OVA and treated with $1 \times 10^{6} \mathrm{BMSCs}$ ), group IV (sensitized and challenged with OVA and treated with $2 \times 10^{6} \mathrm{BMSCs}$ ), and group V (sensitized and challenged with PBS and treated with $1 \times 10^{6}$ BMSCs). Mice in control group were not exposed to any treatment. In groups II, III, and IV, mice were actively immunized intraperitoneally with $10 \mu \mathrm{g}$ of OVA, (Sigma Aldrich, St. Louis, MS, USA) in $4 \mathrm{mg}$ of aluminum hydroxide on Day 0 and Day 7. On Day 14, animals were intranasally challenged with $100-\mu \mathrm{g}$ OVA in $10-\mu \mathrm{l}$ phosphate-buffered saline (PBS) twice a day for 1 week (totally 14 times in a week) (Fig. 1). The immediate reactions of animals after nasal challenge were examined according to $\mathrm{AR}$ symptoms.

\section{Evaluation of symptoms}

AR was evaluated using some parameters, such as the occurrence of typical clinical symptoms, such as eye and nose irritation, conjunctival and nasal secretion, sneezing, and the nasal acoustic phenomenon, reflecting the degree of nasal obstruction. Symptom scores were graded on a fourpoint scale. Each grade was assigned a numeric score between 0 and 3; nasal symptom scores were graded as follows: (a) sneeze: (0) none, (1) for 1-3/10 min, (2) for 4-9/10 min, and (3) for $\geq 10 / 10 \mathrm{~min}$; (b) nasal itching motion: (0) none, (1) rubbing nose for $2 / \mathrm{min}$, (2) rubbing nose for $4-6 / \mathrm{min}$, and (3) rubbing nose for $>6 / \mathrm{min}$; and (c) nasal mucus: (0) none, (1) in a nostril, (2) outside a nostril, and (3) overflowing. Total score should be $>5$ to achieve the successful AR model development [17, 18].

\section{Isolation and cultivation of mesenchymal stem cells from mouse bone marrow}

Mouse mesenchymal stem cells (MSCs) were isolated from the bone marrow aspirates obtained from tibia and femoral parts of the compact bone [19]. The bones were kept in a sterile petri dish, sterilized with $70 \%$ ethanol and then washed with $1 \times$ PBS at least two times. Then, the epiphyses which were localized below the end of the marrow cavity were removed using sterile scissors. A syringe needle was inserted into the bone marrow cavity and the marrow was completely flushed out with PBS until the 
Fig. 1 Timeline of the mouse model of AR and treatment with BMSCs and saline

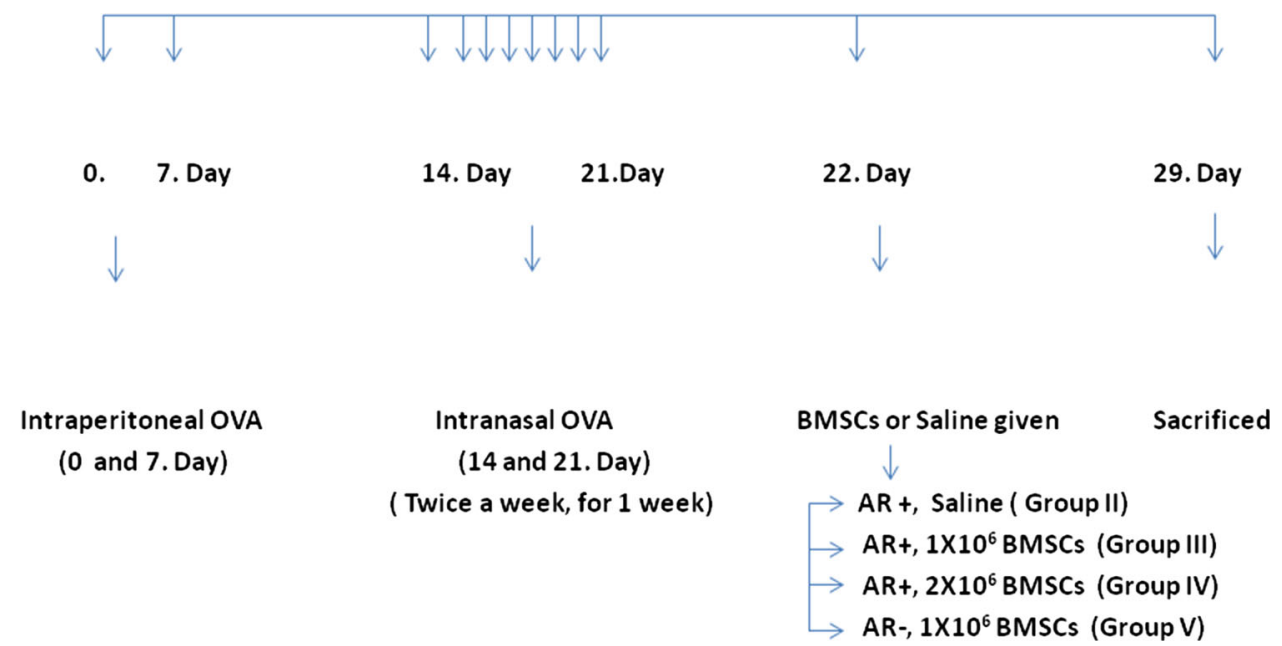

culture flask via trypsinization and counted upon trypan blue staining. BMSCs were suspended in normal saline to introduce them into allergic rhinitis animal models [20].

\section{Characterization of BMSCs}

The cells were incubated with antibodies against NG2 PE (Beckman Coulter), CD45 PC5 (Beckman Coulter, Marsillia, France), CD73 PE (Becton-Dickinson, Bioscience Pharmingen, San Diego, CA, USA), and CD105 FITC (Serotec, Oxford, UK). Fluorescence histograms were obtained by recording 20,000 cells/sample at a flow rate of approximately 200 cell events/s. Experiments were performed using Coulter Epics XL-MCL and flow cytometric data were analyzed using the EXPO 32 ADC software (Beckman Coulter Inc, Miami, FL, USA) [22]. Flow cytometric data analysis demonstrated that there were significant expressions of MSC-specific antigens (CD105, CD73, and NG2) and the absence of hematopoietic marker antigen (CD45) [23].

\section{BMSC and saline administration}

Totally $1 \times 10^{6}$ and $2 \times 10^{6}$ BMSCs were administered to mice via intraperitoneal injection into groups III and IV, respectively. In group II (placebo group), only intraperitoneal saline was supplied.

\section{Evaluation of nasal lavage fluid (NALF)}

Nasal lavage fluid (NALF) was obtained upon the partial tracheal resection using $22 \mathrm{G}$ catheters. The catheter was inserted into the tracheal in the direction of the upper airway into the nasopharynx. The nasal passages were perfused with $1 \mathrm{ml}$ of PBS from the choana to the nostril, and NALF was collected from the nares. 


\section{Histopathological analysis of nasal mucosa and lung tissue}

The mice were anesthetized with the overdose of ketamine after 1 week upon the last BMSC administration. The lung and the head of each mouse were removed and examined in terms of histomorphological changes. Two investigators who were blinded to the treatment groups interpreted the histopathology results. Photomicrographs were taken by Olympus DP25 camera (Japan), which was adapted on an Olympus CX-41 model microscope (Olympus Optical, Tokyo, Japan). The histological images were analyzed using the image analyzer system (CellSens Entry).

\section{Evaluation of nasal tissue}

Mouse heads were fixed in $10 \%$ buffered formalin and decalcified in $10 \%$ EDTA ( $\mathrm{pH} 7.0$ ) for 14 days. The tissues were then embedded into paraffin and 5- $\mu \mathrm{m}$ coronal sections of nasal cavity were obtained. Upon fixation, samples were embedded into paraffin for light microscopic evaluation. Paraffin sections of nasal mucosa were stained with hematoxylin and eosin (H\&E), periodic acid-Schiff (PAS, for goblet cells), and May-Grünwald stain (for eosinophils). Epithelial thicknesses of the nasal septum were measured at $40 \times$ magnification in $\mathrm{H} \& \mathrm{E}$ stained sections. Goblet cells in the nasal epithelium were counted and the results were expressed as the number of goblet cells per $100-\mu \mathrm{m}$ basal lamina. The numbers of eosinophils in the nasal submucosa were counted and the results were expressed as the number of eosinophils/mm of the basal lamina. Histology of the nasal mucosa was evaluated with respect to the epithelial disruption, loss of cilia, goblet cell hyperplasia, and vascular congestion in the nasal mucosa. The parameters were evaluated semi-quantitatively ( $0=$ no change, $1=$ mild change, $2=$ moderate change, and $3=$ severe change) $[24,25]$.

\section{Evaluation of the lung tissue}

Tissue specimens were obtained from the mid zone of the left lung of mice. Lung tissue samples were immediately fixed with $10 \%$ buffered formalin and embedded into paraffin for light microscopic evaluation, and serial sections of $5-\mu \mathrm{m}$ thickness were prepared. For light microscopic evaluation, three different staining processes were used. The first 10 samples were stained with hematoxylin and eosin $(\mathrm{H} \& \mathrm{E})$. In these samples, general tissue features were examined and thicknesses of the epithelium and subepithelial smooth muscle layers of the medium and small airways were measured. To evaluate the thicknesses of epithelium and subepithelial smooth muscle layers, the measurements were performed from 4 points of each airway at the levels of $3,6,9$, and 12 o'clock. The consecutive 10 sections were stained with toluidine blue and the other 10 sections were stained with periodic acid Schiff (PAS). Photomicrographs were taken randomly from 5 fields of each toluidine blue-stained sections. For mast cell enumeration, a standard transparent counting frame representing an area of $16,400 \mu \mathrm{m}^{2}$ was manually used, and 8 fields in each photograph were examined for each mouse. Goblet cells which were stained with PAS were enumerated in 10 sections of each mouse. In each section, randomly selected 3-to-5 airways were photographed. Diameters of all airways were measured and goblet cell numbers were recorded. To analyze whether or not MSCs migrated to the nasal and lung tissues, the confocal microscopic evaluation was performed by a blinded investigator.

\section{Measurements of cytokine levels and differential cell count in NALF}

To evaluate Th2-mediated allergic reactions, IL-4, IL-5, and IL-13 cytokine levels were measured in NALF supernatants of each group using enzyme-linked immunosorbent assay (eBioscience Mouse ELISA kit, USA).

Histological smear samples were prepared. The differential cell count was performed using May-GrünwaldGiemsa staining to classify cells as eosinophils, neutrophils, and lymphocytes on the basis of morphologic criteria and staining characteristics. Differential cell counts were performed in a blinded fashion by counting at least 200 cells per slide under the light microscope.

\section{Measurement of lung nitric oxide (NO) levels}

Nitric oxide levels were measured in supernatants obtained from the lung tissue homogenizations (Invitrogen Griess Reagent) using ELISA in accordance with the manufacturer's recommendations. Griess Reagent (A: 1-naphthylethylene-diamine dihydrochloride, \% 0.1; B: sulfanilic acid, \% 1) was added to samples with an equal volume in microtiter plates (Greiner) and samples were stored at room temperature for $30 \mathrm{~min}$. Results were determined by spectrophotometrically at $548 \mathrm{~nm}$ (BioTek Synergy HT, USA) [26].

\section{Statistical analysis}

SPSS 15 package program was used for the statistical analysis. Data were represented as mean \pm standard deviation (SD). The differences among all groups were compared using the Kruskal-Wallis method. In case, there was a significant difference between two groups, Mann- 
Whitney $U$ test was used for pairwise group comparisons. $p<0.05$ was considered as statistically significant.

\section{Results}

In the current study, histopathological results, cytokine levels, and the migration of BMSCs to the nasal and lung tissues of the groups were evaluated.

\section{Characterization of mesenchymal stem cells and evaluation of nasal and lung tissue migration}

Flow cytometry analysis of the isolated cells from the bone marrow demonstrated that there were significant expressions of MSC-specific antigens (CD105, CD73, and NG2), and no hematopoietic marker antigen (CD45) was detected in any of the cell. While mice in group $\mathrm{V}$ did not have significant BMSCs in their nasal and lung tissues, all mice in group III and IV were shown to have green dots under the confocal microscope indicating that labeled BMSCs migrated to the inflamed nasal and lung tissues. DAPI (4',6-diamidino-2-phenylindole) staining was used to determine the number of nuclei and to assess gross cell morphology (Fig. 2).

\section{Evidence for establishment of AR murine model}

To show the establishment of AR model, we compared the symptomatic scores of AR model groups (groups II, III, and IV) with groups I and V (Table 1; Fig. 3). Symptomatic scores were significantly increased in groups II, III, and IV compared to groups I and V. In group II (placebo), number of goblet cells, eosinophils, and their histological scores was significantly higher compared to the control group. All of these results demonstrated that the AR murine model was successfully established.

\section{Results of histopathological analysis of the nasal tissue}

In group III, the number of goblet cells and eosinophils was significantly lower, but the histological scores were found to be similar when compared to the placebo group. In group IV, all parameters (the number of goblet cells, eosinophils, and histological scores) were significantly lower compared to the placebo group (Table 2; Figs. 4, 5).

\section{Results of histopathological analysis of the lung tissue}

In addition to histological findings observed in lung tissues of groups II, III, and IV, there were also histopathological findings of chronic asthma in lung tissues of these groups. In groups II, III, and IV, histological findings of chronic asthma, such as the number of mast and goblet cells, and epithelial and subepithelial smooth muscle layer thicknesses were significantly higher compared to the control group. While only subepithelial smooth muscle layer thicknesses and epithelium thicknesses were significantly lower in group III, all of the histological parameters of chronic asthma (the number of mast and goblet cells, and epithelial and subepithelial smooth muscle layer thicknesses) were significantly lower in group IV compared to the placebo group (Table 3; Figs. 6, 7a, b).
Fig. 2 Confocal microscopic images of nasal and lung tissues of groups II and IV (A1 confocal microscopic images of nasal tissue and A2 confocal microscopic images of lung tissue of group II and B1 confocal microscopic images of nasal tissue and B2 confocal microscopic images of lung tissue of group IV). DAPI $4^{\prime}, 6$ diamidino-2-phenylindole, $G F P$ green fluorescent protein)
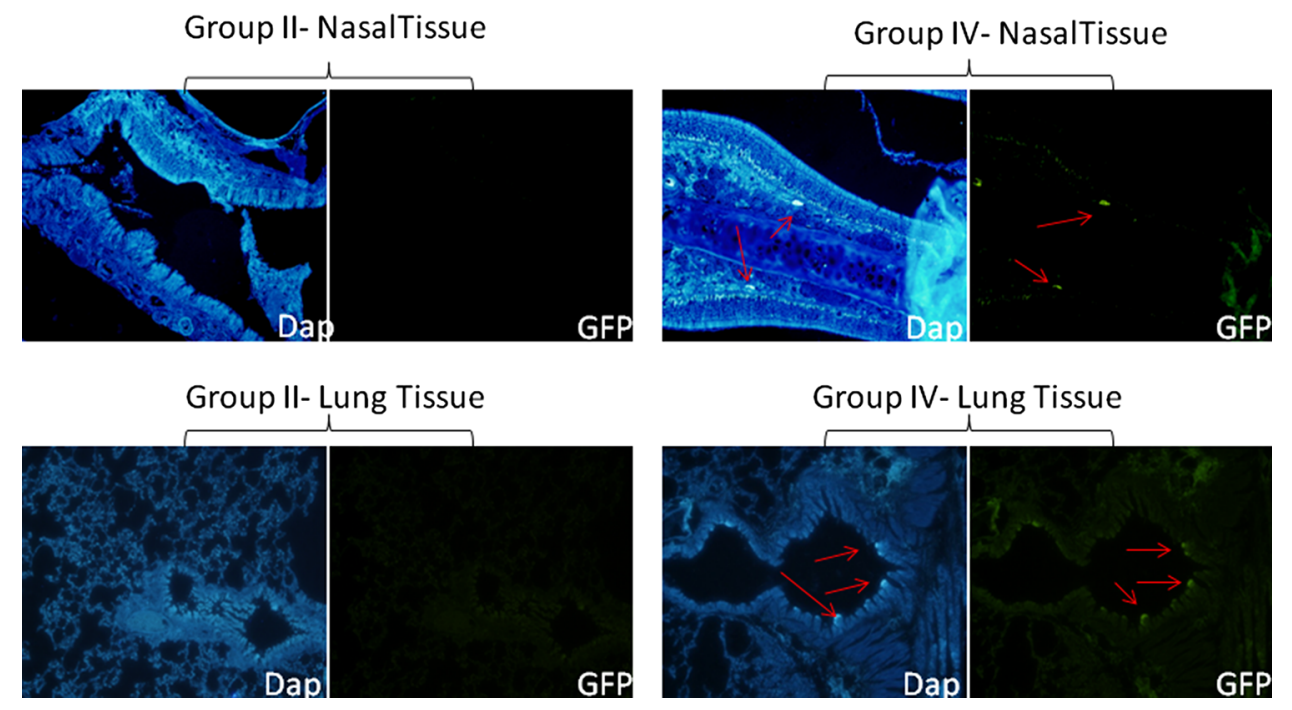
Table 1 Comparison of AR symptom scores of study groups $($ mean $\pm \mathrm{SD})$

\begin{tabular}{lllr}
\hline & $\begin{array}{l}\text { AR-positive groups } \\
\text { (groups II, III, IV) }(\text { mean } \pm \mathrm{SD})\end{array}$ & $\begin{array}{l}\text { AR-negative groups } \\
\text { (groups I and V) }(\text { mean } \pm \mathrm{SD})\end{array}$ & $p$ \\
\hline Number of sneeze/10 min & $18.6 \pm 7.7$ & $3.7 \pm 2.2$ & 0.00 \\
Number of nasal rubbing/min & $10.8 \pm 10.7$ & $1.7 \pm 1.0$ & 0.03 \\
Nasal mucous & $0.00 \pm 0.00$ & $0.00 \pm 0.00$ & 0.00 \\
\hline
\end{tabular}

Table 2 Histopathological findings of nasal tissue (mean \pm SD)

\begin{tabular}{|c|c|c|c|c|c|}
\hline & $\begin{array}{l}\text { Group I } \\
(\text { control) } \\
(\text { mean } \pm \mathrm{SD})\end{array}$ & $\begin{array}{l}\text { Group II } \\
\text { (placebo-AR+, saline) } \\
(\text { mean } \pm \mathrm{SD})\end{array}$ & $\begin{array}{l}\text { Group III } \\
\left(\mathrm{AR}+, 1 \times 10^{6} \mathrm{MSC}\right) \\
(\text { mean } \pm \mathrm{SD})\end{array}$ & $\begin{array}{l}\text { Group IV } \\
\left(\mathrm{AR}+, 2 \times 10^{6} \mathrm{MSC}\right) \\
(\text { mean } \pm \mathrm{SD})\end{array}$ & $\begin{array}{l}\text { Group V } \\
\left(\mathrm{AR}-, 1 \times 10^{6} \mathrm{MSC}\right) \\
(\text { mean } \pm \mathrm{SD})\end{array}$ \\
\hline $\begin{array}{l}\text { Number of goblet cells/ } \\
100 \mu \mathrm{m} \text { basal lamina }\end{array}$ & $1.06 \pm 0.15^{*}$ & $2.57 \pm 0.39$ & $1.32 \pm 0.20^{*}$ & $0.92 \pm 0.11^{*}$ & $0.94 \pm 0.14^{*}$ \\
\hline $\begin{array}{l}\text { Number of eosinophil/ } \\
\text { mm basal lamina }\end{array}$ & $2.63 \pm 0.46^{*}$ & $6.81 \pm 0.57$ & $3.07 \pm 0.39 *$ & $2.87 \pm 0.44 *$ & $2.58 \pm 0.51^{*}$ \\
\hline Histological scores & $0.0 \pm 0^{*}$ & $2.0 \pm 0.31$ & $1.0 \pm 0.25$ & $0.85 \pm 0.26^{*}$ & $0.2 \pm 0.2 *$ \\
\hline
\end{tabular}

$* p<0.05$ in groups versus placebo (group II)

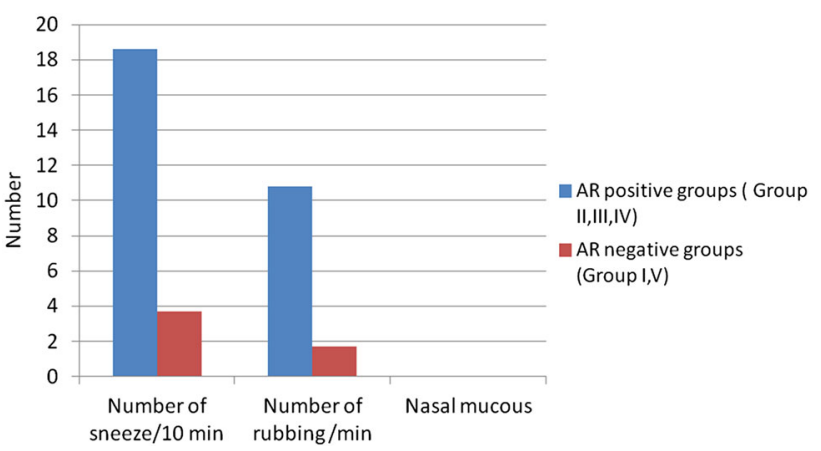

Fig. 3 Correlation graphics' comparison of AR symptom scores of study groups

\section{Results of cytokine levels and differential cell count in NALF}

All of the cytokines (IL-4, IL-5, and IL-13) and NO levels of the placebo group were significantly higher compared to groups III and IV (Table 4; Fig. 8). In group IV, levels of all cytokines and $\mathrm{NO}$ were significantly lower compared to group III. The numbers of eosinophils in NALF were significantly reduced in both groups receiving BMSCs when compared to the placebo group. However, the percentage of eosinophils was minimum in the control group and maximum in the placebo group.

According to the all results, we have shown that at higher dose of $\left(2 \times 10^{6}\right)$ BMSCs migrate to lung and nasal tissues upon their intraperitoneal administration in the murine model of AR and more effective than at lower dose of $\left(1 \times 10^{6}\right)$ BMSCs on the remodeling and eosinophilic inflammation in both upper and lower airways by suppressing the Th2 immune response.

\section{Discussion}

Allergic rhinitis (AR) is the most common chronic condition in both adult and pediatric populations, affecting 10 to $30 \%$ of adult and 20 to $40 \%$ of children [1]. Presentation of an allergen to lymphocytes leads to the Th2 cytokine release, such as IL-4, IL-5, and IL-13, which promote IgE production and the infiltration of the inflammatory cells, such as eosinophils and mast cells to the mucosa. Even though medical treatment is the cornerstone of AR management, the recurrence of symptoms and the development of adverse effects are common problems due to the drug withdrawal. Therefore, new and promising definitive treatment options are required for AR.

Mesenchymal stem cells (MSCs) are multipotent progenitor cells which were first identified in the bone marrow and they have the ability to differentiate into bone, fat, and cartilage [27]. In addition to their potential for tissue repair, MSCs possess also potent anti-proliferative, anti-fibrotic, and anti-inflammatory and immunomodulatory effects $[28,29]$ which can support their therapeutic usage in immune-mediated diseases. Their protective roles have been described in airway diseases, such as acute lung injury [6], pulmonary fibrosis [7], and, more recently, asthma [19] and allergic rhinitis [13]. MSCs, in general, have established a very good safety profile as validated through numerous clinical studies. Multiple clinical studies have shown its safety in the treatment of Crohn's disease, steroid resistant graft versus host disease, multiple sclerosis and amyotrophic lateral sclerosis, chronic obstructive pulmonary disease, and multiple other inflammatory and degenerative conditions [30-33]. 


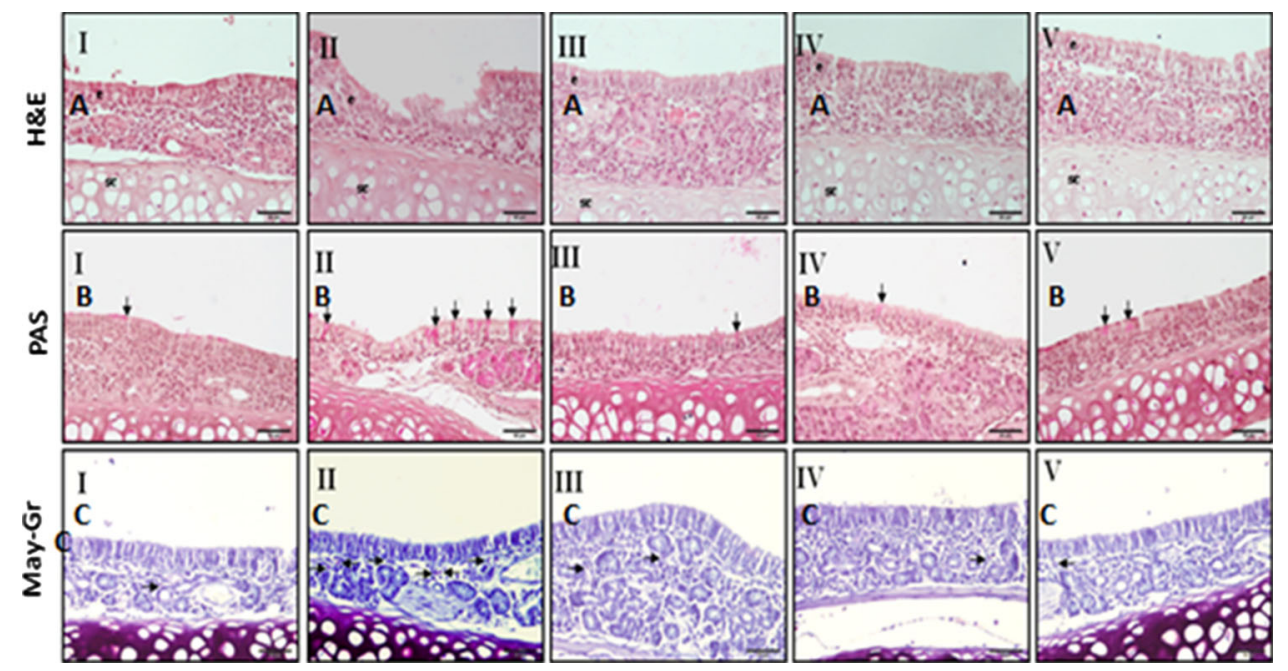

Fig. 4 Light microscopic results of the groups belonging to the nasal tissue. I Control, II placebo group, III AR developed and $1 \times 10^{6}$ BMSCs-treated group, IV AR developed and $2 \times 10^{6}$ BMSCs-treated group, $V$ non-AR and $1 \times 10^{6}$ BMSCs-treated group. In representative histological images, nasal tissues were stained with H\&E (a; 1 st row), PAS (b; 2nd row), and May-Grünwald (c; 3rd row). In placebo group, H\&E staining revealed increased cell size, vascular congestion, and epithelial damage (a II), PAS staining revealed goblet cell hyperplasia in the respiratory epithelium overlying nasal septum

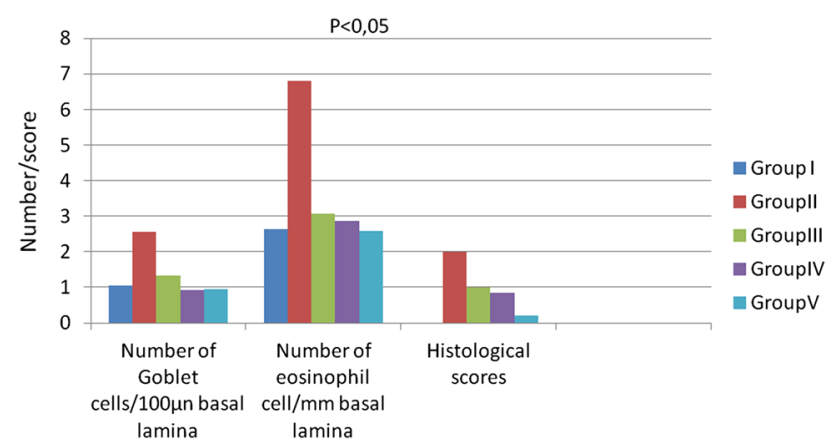

Fig. 5 Correlation graphics' histopathological findings of nasal tissues

Asthma is another disease closely related to AR. These two pathologies: asthma and allergic rhinitis occur due to similar pathogenic processes in different segments of airways. However, it has recently been shown in literature that these two diseases are associated with each other. The presence of AR significantly predisposes to the development of asthma later in life. Increased levels of inflammatory factors in the blood and propagation of the inflammation through the airway or systemic pathways can be possible mechanisms for lower airway dysfunction among patients with upper airway diseases, such as AR. When both diseases coexist, it is known that treating AR can also lead to improvement in symptoms and severity of asthma [34]. (black arrows, b II) and high number of eosinophil were seen with May-Grünwald staining (black arrow, c III). In the group III, IV, pathological changes, goblet cell hyperplasia, and numbers of eosinophils were significantly less compared to the placebo group (b $I V, \mathbf{c} I V$ ). Histological scores of nasal mucosa, including epithelial disruption, loss of cilia, goblet cell hyperplasia, chondrocyte hypertrophy, and vascular congestion, were significantly decreased in group IV compared to the placebo group, and there were no differences between group III and the placebo group

For the first time in this study, it has been shown that BMSCs migrate to the nasal mucosa upon their intraperitoneal administration in murine model of AR. Furthermore, it has also been indicated that BMCSs have positive effects on histopathological findings, Th2 immune responses, and NO levels.

In the present study, we have also observed various histopathological findings of chronic asthma and migration of BMSCs to the lung tissue of murine model of AR. We have found that groups II, III, and IV mice have histopathological findings of chronic asthma, such as increased number of the mast and goblet cells, and epithelial and subepithelial smooth muscle layer thicknesses in addition to histopathological findings of AR.

The immunoregulatory effects of MSCs are mainly mediated through direct cell-to-cell interactions and paracrine effects [35]. Thus, the recruitment of MSCs to the sites of inflammation and injury is very important. The optimal route for stem cell transplantation is another issue which needs to be determined before its clinical applications. In contrast to a normal lung, an injured lung produces soluble factors that induce MSCs proliferation and the recruitment toward an injured lung [6]. Moreover, systemically administered MSCs have been shown to localize to an injured lung [36]. A recent study has also shown that human MSCs which were administered by intraperitoneal injection could be implanted into the lungs of newborn rats, and they could effectively protect the rats against lung 
Table 3 Histopathological findings of lung tissue (mean \pm SD)

\begin{tabular}{|c|c|c|c|c|c|}
\hline & $\begin{array}{l}\text { Group } 1 \\
(\text { control) } \\
(\text { mean } \pm \mathrm{SD})\end{array}$ & $\begin{array}{l}\text { Group II } \\
\text { (placebo-AR+, saline) } \\
(\text { mean } \pm \text { SD) }\end{array}$ & $\begin{array}{l}\text { Group III } \\
\left(\mathrm{AR}+, 1 \times 10^{6} \mathrm{MSC}\right) \\
(\text { mean } \pm \mathrm{SD})\end{array}$ & $\begin{array}{l}\text { Group IV } \\
\left(\mathrm{AR}+, 2 \times 10^{6} \mathrm{MSC}\right) \\
(\text { mean } \pm \mathrm{SD})\end{array}$ & $\begin{array}{l}\text { Group V } \\
\left(\mathrm{AR}-, 1 \times 10^{6} \mathrm{MSC}\right) \\
(\text { mean } \pm \mathrm{SD})\end{array}$ \\
\hline $\begin{array}{l}\text { Epithelium thickness } \\
(\mu \mathrm{m})\end{array}$ & $011.39 \pm 0.63 *$ & $15.18 \pm 0.54$ & $11.94 \pm 0.39 *$ & $12.21 \pm 0.35^{*}$ & $12.69 \pm 0.65^{*}$ \\
\hline $\begin{array}{l}\text { Number of goblet cells/ } \\
100 \mu \mathrm{m}\end{array}$ & $0.24 \pm 0.07^{*}$ & $2.31 \pm 0.39$ & $1.26 \pm 0.34$ & $0.74 \pm 0.20^{*}$ & $0.77 \pm 0.24 *$ \\
\hline $\begin{array}{l}\text { Subepithelial smooth } \\
\text { muscle thickness }(\mu \mathrm{m})\end{array}$ & $5.82 \pm 0.14^{*}$ & $10.21 \pm 0.33$ & $6.41 \pm 0.35^{*}$ & $6.45 \pm 0.37 *$ & $5.9 \pm 0.38^{*}$ \\
\hline $\begin{array}{l}\text { Number of mast cells/ } \\
20,000 \mu \mathrm{m}^{2}\end{array}$ & $0.27 \pm 0.11^{*}$ & $1.31 \pm 0.32$ & $0.67 \pm 0.13^{*}$ & $0.54 \pm 0.10^{*}$ & $0.49 \pm 0.13^{*}$ \\
\hline
\end{tabular}

$* p<0.05$ in groups versus placebo (group II)

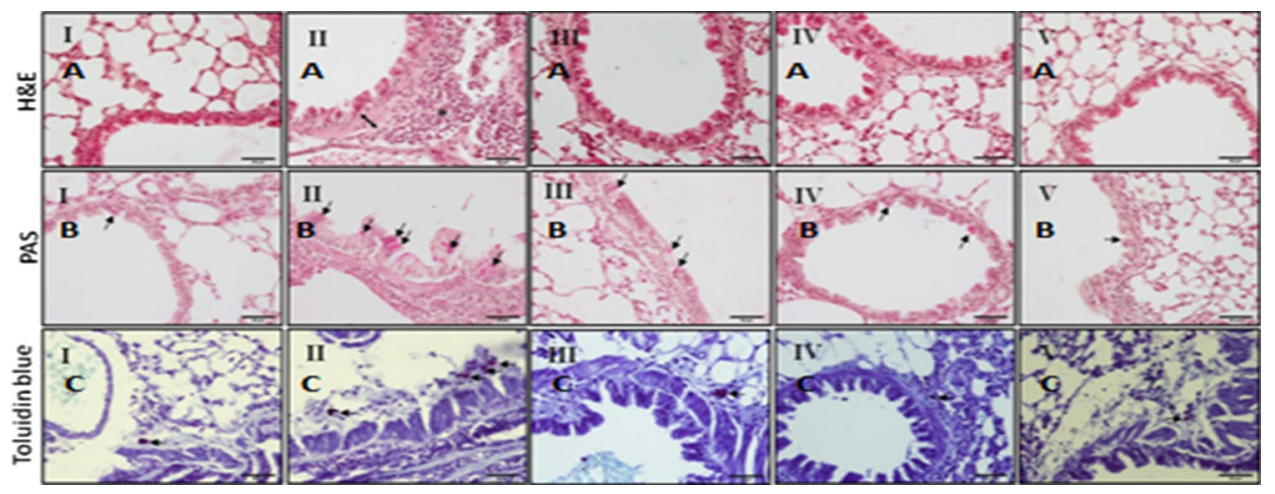

Fig. 6 Light microscopic findings of the groups belonging to the lung tissue. I Control, II placebo group, III AR developed and $1 \times 10^{6}$ BMSCs-treated group, IV AR developed and $2 \times 10^{6}$ BMSCs-treated group, $V$ non-AR, $1 \times 10^{6}$ BMSCs-treated group. In representative histological images, lung tissues were stained with $\mathrm{H} \& \mathrm{E}$ (a; 1st row), PAS (b; 2nd row), Toluidin blue (c; 3rd row), and electron microscopic views (d; 4th). In control group, light microscopic findings revealed a regular, normal bronchiole wall thickness, bronchiole lumen (a I). In placebo group, H\&E staining (a II) revealed thickened epithelium, thickened subepithelial smooth muscle (arrow with two heads), and peribronchial mononuclear infiltration

damage to due to the hyperoxia [37]. In this study, it was primarily shown that BMSCs migrated into both nasal and lung tissues of group III and IV mice following an intraperitoneal delivery of BMSCs.

Allergic rhinitis (AR) and asthma are characterized by skewed Th2 cells, eosinophilic inflammation, mucus hypersecretion, and airway hyperresponsiveness [1]. The excessive activation of Th2 cells is thought to play a major role in the initiation of clinical features, including allergic sensitization and driving airway hyperresponsiveness [38]. Few published reports evaluating effects of MSCs on CD4 $\mathrm{T}$ lymphocyte differentiation generally demonstrate that MSCs tend to shift CD4 T lymphocytes toward a Th2 phenotype both in vitro and in vivo [39, 40]. These findings suggest that administration of MSCs might be either ineffective or can potentially exacerbate immune responses in a (asterisk). High numbers of goblet cells were seen with PAS staining (b II) (arrow with one head), and mast cells with toluidine blue staining (c II) (arrow with one head). Only in group IV, all of the histological parameters (epithelium thickness, subepithelial smooth muscle thickness, number of goblet, and mast cells) have improved compared to the placebo group (black arrow). In group III, epithelium thickness and subepithelial smooth muscle thickness were significantly less than the placebo group, and no statistical difference was found in the number of goblet and mast cells (b III, c III) between both groups

model of Th2-mediated inflammation, such as allergic asthma. However, there are lots of opposed studies in the literature in this field.

In our study, it was observed in group III and group IV (BMCSs administered groups) that eosinophilic inflammation in both nasal and lung tissues and IL-4, IL-5, and IL-13 cytokine levels (signs of Th2 immune response in BAL fluid) were suppressed. In a recent study, in which a mouse model of OVA-induced Th2-mediated eosinophilic allergic airways inflammation was used, authors found that systemic administration of either syngeneic or allogeneic BMSCs during the antigen sensitization process inhibited both airways hyperreactivity and lung inflammation through a mechanism partly dependent on IFN-gamma [41]. Syngeneic adipose-derived MSCs (ASCs) were also shown to inhibit both OVA-induced allergic rhinitis and 


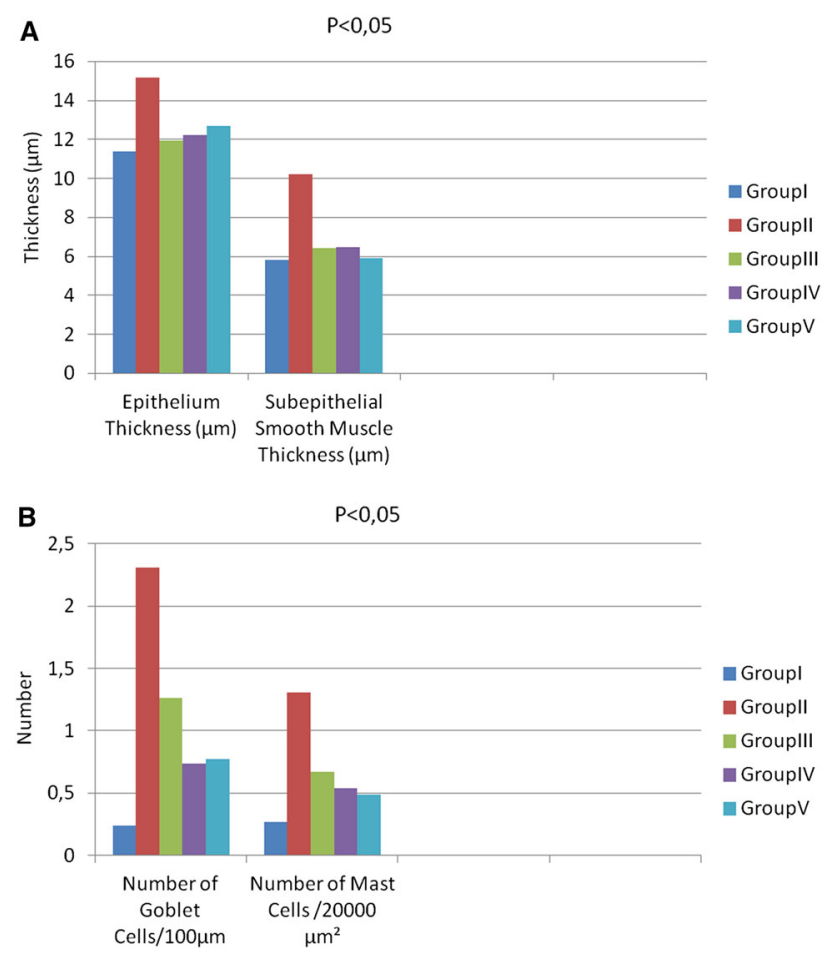

Fig. 7 a, b Correlation graphics' histopathological findings of lung tissues

allergic airways inflammation when administered during or before the antigen challenge in previously sensitized mice. ASCs appeared to promote Th1 activation as measured by IFN-gamma levels in the BAL fluid. Besides, polyclonally activated CD4 $\mathrm{T}$ lymphocytes were recovered from BAL and spleen and they were stained positively for intracellular IFN-gamma [42]. In another study, the immunomodulatory effects of mesenchymal stem cells derived from humaninduced pluripotent stem cells (iPSC-MSCs) and BMSCs on lymphocyte proliferation, T-cell phenotypes and cytokine production in peripheral blood mononuclear cells were compared in patients with AR. Conclusively, the possible molecular mechanisms underlying the immunomodulatory properties of iPSC-MSCs were shown. Accordingly, authors demonstrated that iPSC-MSCs were

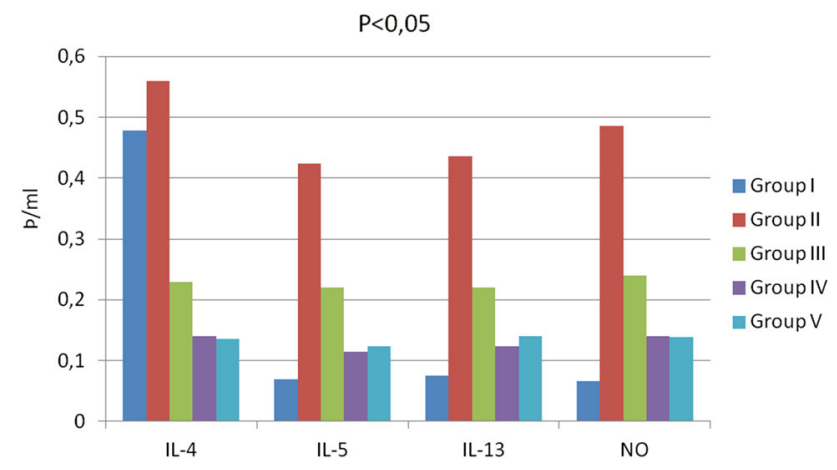

Fig. 8 Correlation graphics' cytokine levels in nasal lavage fluid and lung homogenants

capable of modulating T-cell phenotypes towards $\mathrm{Th} 2$ suppression by inducing the Treg expansion [43]. Abreu et al. compared the effects of bone marrow-derived mononuclear cells (BMMCs) and mesenchymal stromal cells (MSCs) on airway inflammation and remodeling and lung mechanics in an experimental allergic asthma model. They demonstrated that both BMMCs and MSC administration decreased the cell infiltration, bronchoconstriction index, alveolar collapse, collagen fiber content in the alveolar septa, interleukin IL-4, IL-13, transforming growth factor (TGF), and vascular endothelial growth factor (VEGF) levels compared to placebo samples [44]. Another study showed that human MSCs administered upon the induction of airway disease dramatically decreased the pathology and airway inflammation associated with the OVA albumin model of chronic asthma, which may be related to the modulation of IL-5, IL-13, IgE, and inducible nitric oxide synthase (INOS) expression [11]. In our study, Th2 cytokines and number of eosinophils in NALF fluid and NO levels of BMSC-treated groups (groups III and IV) were significantly lower compared to the placebo group. Furthermore, similar to the study of Bonfield et al., BMSCs administration in both groups (groups III and IV) improved the nasal and lung histopathology of diseases, such as AR and asthma. Administration of BMSCs to group $\mathrm{V}$ mice was well

Table 4 Cytokine levels in nasal lavage fluid and lung homogenants (mean \pm SD)

\begin{tabular}{llllll}
\hline & $\begin{array}{l}\text { Group I } \\
(\text { control) } \\
(\text { mean } \pm \text { SD) }\end{array}$ & $\begin{array}{l}\text { Group II (placebo- } \\
\text { AR+, saline) } \\
(\text { mean } \pm \text { SD) }\end{array}$ & $\begin{array}{l}\text { Group III (AR+, } \\
\left(\times 10^{6} \text { MSC) }\right. \\
(\text { mean } \pm \text { SD) }\end{array}$ & $\begin{array}{l}\text { Group IV (AR+, } \\
2 \times 10^{6} \text { MSC) } \\
(\text { mean } \pm \text { SD) }\end{array}$ & $\begin{array}{l}\text { Group V (AR-, } \\
1 \times 10^{6} \text { MSC) } \\
(\mathrm{mean} \pm \mathrm{SD})\end{array}$ \\
\hline $\mathrm{IL}-4(\mathrm{pg} / \mathrm{ml})(\mathrm{NALF})$ & $0.056 \pm 0.040^{*}$ & $0.478 \pm 0.045$ & $0.141 \pm 0.031^{*}$ & $0.230 \pm 0.031^{*}$ & $0.135 \pm 0.029^{*}$ \\
$\mathrm{IL}-\mathrm{S}(\mathrm{pg} / \mathrm{ml})(\mathrm{NALF})$ & $0.069 \pm 0.024^{*}$ & $0.424 \pm 0.056$ & $0.115 \pm 0.043^{*}$ & $0.220 \pm 0.045^{*}$ & $0.123 \pm 0.014^{*}$ \\
$\mathrm{IL}-13(\mathrm{pg} / \mathrm{ml})(\mathrm{NALF})$ & $0.076 \pm 0.028^{*}$ & $0.436 \pm 0.052$ & $0.123 \pm 0.025^{*}$ & $0.220 \pm 0.063^{*}$ & $0.140 \pm 0.042^{*}$ \\
$\begin{array}{l}\text { No }(\mu \mathrm{M})(\mathrm{lung} \\
\text { homogenants) }\end{array}$ & $0.067 \pm 0.041^{*}$ & $0.486 \pm 0.068$ & $0.140 \pm 0.065^{*}$ & $0.240 \pm 0.032^{*}$ & $0.139 \pm 0.049^{*}$ \\
\hline
\end{tabular}

$* p<0.05$ in groups versus placebo (group II) 
tolerated and it did not affect any of measurements of nasal and lung inflammation or levels of Th2 cytokines and NO compared to control mice. This is an important observation which highlights a specific immunomodulatory role of BMSCs only under conditions of immune stimulation or disruption. Conclusively, it is shown in this study that BMSCs migrate to lung and nasal tissues upon their intraperitoneal administration in the murine model of AR and ameliorate the remodeling and eosinophilic inflammation in both upper and lower airways by suppressing the Th2 immune response. The present data are compatible with the previous studies which were performed on the MSCs treatment for allergic airway inflammation. Further research is needed to assess the favorable effects of BMSC therapy in these aspects in human asthma and AR.

\section{Compliance with ethical standards}

The authors declare that they have no conflict of interest.

This project was supported by Dokuz Eylul University Scientific Research Foundation Grant BAP-Project no.2012.KB.SAG.088.

All applicable international, national, and/or institutional guidelines for the care and use of animals were followed.

\section{References}

1. Meltzer EO, Blaiss MS, Derebery MJ et al (2009) Burden of allergic rhinitis: results from the Pediatric Allergies in America survey. J Allergy Clin Immunol 124:43-70

2. Durham SR, Ying S, Varney VA, Jacobson MR, Sudderick RM, Mackay IS (1992) Cytokine messenger RNA expression for IL-3, IL-4, IL-5 and granulocyte/macrophage-colony-stimulating factor in the nasal mucosa after local allergen provocation: relationship to tissue eosinophilia. J Immunol 148:2390-2394

3. Delorme B, Charbord P (2007) Culture and characterization of human bone marrow mesenchymal stem cells. Methods Mol Med 140:67-81

4. Pittenger MF, Mackay AM, Beck SC, Jaiswal RK, Douglas R, Mosca JD et al (1999) Multilineage potential of adult human mesenchymal stem cells. Science 284:143-147

5. Iyer SS, Co C, Rojas M (2009) Mesenchymal stem cells and inflammatory lung diseases. Panminerva Med 51:5-16

6. Rojas M, Xu J, Woods CR, Mora AL, Spears W, Roman J et al (2005) Bone marrow-derived mesenchymal stem cells in repair of the injured lung. Am J Respir Cell Mol Biol 33:145-152

7. Grupta N, Su X, Popov B, Lee JW, Serikov V, Matthay MA (2007) Intrapulmonary delivery of bone marrow-derived mesenchymal stem cells improves survival and attenuates endotoxininduced acute lung injury in mice. J Immunol 179:1855-1863

8. Xu J, Woods CR, Mora AL, Joodi R, Brigham KL, Iyer S et al (2007) Prevention of endotoxin induced systemic response by bone marrow-derived mesenchymal stem cells in mice. Am J Physiol Lung Cell Mol Physiol 293:131-141

9. Sun YQ, Deng MX, He J, Zeng QX, Wen W, Wong DS, Tse HF, Xu G, Lian Q, Shi J, Fu QL (2012) Human pluripotent stem cellderived mesenchymal stem cells prevent allergic airway inflammation in mice. Stem Cells 30(12):2692-2699

10. Nemeth K, Keane-Myers A, Brown JM et al (2010) Bone marrow stromal cells use TGF-beta to supress allergic responses in a mouse model of ragweed-induced asthma. Proc Natl Acad Sci USA 107:5652-5657
11. Bonfield TL, Koloze M, Lennon DP et al (2010) Human mesenchymal stem cells supress chronic airway inflammation in the murine ovaalbumin asthma model. Am J Physiol Lung Cell Mol Physiol 299:760-770

12. Bonfield TL, Nolan Koloze MT, Lennon DP et al (2007) Defining human mesenchymal stem cell efficacy in vivo. J Inflamm (Lond) 7:51

13. Cho KS, Roh HJ (2010) Immunomodulatory effects of adiposederived stem cells in airway allergic diseases. Curr Stem Cell Res Ther 5:111-115

14. Kavanagh H, Mahon BP (2011) Allogeneic mesenchymal stem cells prevent allergic airway inflammation by inducing murine regulatory T cells. Allergy 66:523-531

15. Temelkovski J, Hogan SP, Shepherd DP, Foster PS, Kumar RK (1998) An improved murine model of asthma: selective airway inflammation, epithelial lesions and increased methacholine responsiveness following chronic exposure to aerosolised allergen. Thorax 53:849-856

16. Ouyang Y, Nakao A, Han D, Zhang L (2012) Transforming growth factor- $\beta 1$ promotes nasal mucosal mast cell chemotaxis in murine experimental allergic rhinitis. ORL J Otorhinolaryngol Relat Spec 74(3):117-123

17. Brozmanova M, Calkovsky V, Plevkova J, Bartos V, Tatar M, Plank L (2006) Early and late allergic phase related cough response in sensitized guinea pigs with experimental allergic rhinitis. Physiol Res 55:577-584

18. Assanasen P, Baroody FM, Rouadi P, Naureckas E, Solway J, Naclerio RM (2000) Ipratropium bromide increases the ability of the nose to warm and humidify air. Am J Respir Crit Care Med 162:1031-1037

19. Firinci F, Karaman M, Baran Y et al (2011) Mesenchymal stem cells ameliorate the histopathological changes in a murine model of chronic asthma. Int Immunopharmacol 11(8):1120-1126

20. Sunay O, Can G, Cakir Z, Denek Z, Kozanoğlu I, Erdil G, Mustafa M, Baran Y (2013) Autologous rabbit adipose tissue derived mesenchymal stem cells for the treatment of bone injuries with distraction osteogenesis. Cytotherapy 15(6):690-702

21. Baran Y, Ural AU, Avcu F, Sarper M, Elçi P, Pekel A (2008) Optimisation of transfection of green fluorescent protein in pursuing mesenchymal stem cells, in vivo. Turk J Hematol 25:172-175

22. Loebinger MR, Aguilar S, Janes SM (2008) Therapeutic potential of stem cells in lung disease: progress and pitfalls. Clin Sci (Lond) 114(2):99-108

23. Kozanoglu I, Boga C, Ozdogu H, Sozer O, Maytalman E et al (2009) Human bone marrow mesenchymal cells express NG2: possible increase in discriminative ability of flow cytometry during mesenchymal stromal cell identification. Cytotherapy 11:527-533

24. Salib RJ, Howarth PH (2003) Remodelling of the upper airways in allergic rhinitis: is it a feature of the disease? Clin Exp Allergy 33:1629-1633

25. Bousquet J, Jacquot W, Vignola A, Bachert C et al (2004) Allergic rhinitis: a disease remodelling the upper airways? J Allergy Clin Immunol 113:43-49

26. Green LC, Wagner DA, Glogowski J, Skippper PL, Wishnok JS, Tannenbaum SR (1982) Analysis of nitrate, nitrite, and [15N] nitrite in biological fluids. Anal Biochem 126:131-138

27. Friedenstein AJ, Chailakhyan RK, Latsinik NV et al (1974) Stromal cells responsible for transferring the microenvironment of the hemopoietic tissues. Cloning in vitro and retransplantation in vivo. Transplantation 17:331-340

28. Weiss DJ, Kolls JK, Ortiz LA et al (2008) Stem cells and cell therapies in lung biology and lung diseases. Proc Am Thorac Soc 5:637-667

29. Keating A (2006) Mesenchymal stromal cells. Curr Opin Hematol 13:419-425 
30. Le Blanc K, Frassoni F, Ball L, Locatelli F, Roelofs H, Lewis I, Lanino E, Sundberg B, Bernardo ME, Remberger M, Dini G, Egeler RM, Bacigalupo A, Fibbe W, Ringd'en O (2008) Developmental Committee of the European Group for Blood and Marrow Transplantation: mesenchymal stem cells for treatment of steroid-resistant, severe, acute graft-versus-host disease: a phase II study. The Lancet 371:1579-1586

31. Karussis D, Karageorgiou C, Vaknin-Dembinsky A, GowdaKurkalli B, Gomori JM, Kassis I, Bulte JW, Petrou P, Ben-Hur T, Abramsky O, Slavin S (2010) Safety and immunological effects of mesenchymal stem cell transplantation in patients with multiple sclerosis and amyotrophic lateral sclerosis. Arch Neurol 67:1187-1194

32. Weiss DJ, Casaburi R, Flannery R, LeRoux-Williams M, Tashkin DP (2013) A placebo-controlled, randomized trial of mesenchymal stem cells in COPD. Chest J Chest 143:1590-1598

33. Duijvestein M, Vos ACW, Roelofs H, Wildenberg ME, Wendrich BB, Verspaget HW, Kooy-Winkelaar EM, Koning F, Zwaginga JJ, Fidder HH, Verhaar AP, Fibbe WE, van den Brink GR, Hommes DW (2010) Autologous bone marrow-derived mesenchymal stromal cell treatment for refractory luminal Crohn's disease: results of a phase I study. Gut 59:1662-1669

34. Shaaban R, Zureik M, Soussan D, Neukirch C, Heinrich J, Sunyer $\mathrm{J}$ et al (2008) Rhinitis and onset of asthma: a longitudinal population based study. Lancet 372:1049-1057

35. Le Blanc K, Ringde'n O (2007) Immunomodulation by mesenchymal stem cells and clinical experience. J Intern Med 262:509-525

36. Ortiz LA, Gambelli F, McBride C, Gaupp D, Baddoo M, Kaminski N, Phinney DG (2003) Mesenchymal stem cell engraftment in lung is enhanced in response to bleomycin exposure and ameliorates its fibrotic effects. Proc Natl Acad Sci 14:8407-8411

37. Tian ZF, Du J, Fu XM, Wang B, Hong XY, Feng ZC (2008) Influence of human bone marrow-derived mesenchymal stem cells on the lung of newborn rats damaged by hyperoxia. Zhonghua Er Ke Za Zhi 46(1):4-8

38. Galli SJ, Tsai M, Piliponsky AM (2008) The development of allergic inflammation. Nature 454:445-454

39. Bai L, Lennon DP, Eaton V et al (2009) Human bone marrowderived mesenchymal stem cells induce Th2-polarized immune response and promote endogenous repair in animal models of multiple sclerosis. Glia 57:1192-1203

40. Aggarwal S, Pittenger MF (2005) Human mesenchymal stem cells modulate allogeneic immune cell responses. Blood 105:1815-1822

41. Goodwin M, Sueblinvong V, Eisenhauer P, Ziats NP, LeClair L, Poynter ME, Steele C, Rincon M, Weiss DJ (2011) Bone marrow derived mesenchymal stromal cells inhibit Th2-mediated allergic airways inflammation in mice. Stem Cells 29(7):1137-1148

42. Park HK, Cho KS, Park HY, Shin DH, Kim YK, Jung JS, Park SK, Roh HJ (2010) Adipose-derived stromal cells inhibit allergic airway inflammation in mice. Stem Cells Dev 19(11):1811-1818

43. Fu QL, Chow YY, Sun SJ, Zeng QX, Li HB, Shi JB, Sun YQ, Wen W, Tse HF, Lian Q, Xu G (2012) Mesenchymal stem cells derived from human induced pluripotent stem cells modulate T-cell phenotypes in allergic rhinitis. Allergy 67(10):1215-1222

44. Abreu SC, Antunes MA, de Castro JC, de Oliveira MV, Bandeira E, Ornellas DS, Diaz BL, Morales MM, Xisto DG, Rocco PR (2013) Bone marrow derived mononuclear cells vs. mesenchymal stromal cells in experimental allergic asthma. Respir Physiol Neurobiol 187(2):190-198 